\title{
Peningkatan Nilai Tambah Tailing Tambang Mangan Menjadi Bata Cetak Tanpa Pembakaran Pada UMK Tambang di Desa Setiawaras, Kec. Cibalong, Kab. Tasikmalaya
}

\author{
Edvin Priatna ${ }^{1}$, Pengki Irawan ${ }^{2}$, Aripin $^{3}$ \\ 1,3Jurusan Teknik Elektro, Fakultas Teknik, Universitas Siliwangi Tasikmalaya \\ ${ }^{2}$ Jurusan Teknik Sipil, Fakultas Teknik, Universitas Siliwangi Tasikmalaya \\ Email: ujack05@yahoo.com¹,irawan@unsil.ac.id²,aripin@unsil.ac.id ${ }^{3}$
}

\begin{abstract}
ABSTRAK
Selama 2014-2016, produksi total bijih mangan rakyat di Desa Setiawaras, Kec. Cibalong, Kab. Tasikmalaya adalah sekitar 2.520 ton/tahun. Untuk setiap ton bijih mangan yang dihasilkan, dua ton tailing bijih mangan dikeluarkan. Berdasarkan tingkat produksi saat ini, dapat diperkirakan bahwa sekitar 5.040 ton tailing tambang bijih mangan diproduksi setiap tahun di Desa Setiawaras. Tailing bijih mangan ini ditinggalkan begitu saja di pinggir-pinggir jalan, kolam penampungan, tempat-tempat kosong dan area pertambangan. Oleh karena itu, perlu dilakukan terobosan yang dapat membantu memanfaatkan tailing mangan yang melimpah dan juga bantuan dalam penyiapan teknologi pengolahan. Metode pelaksanaan pelatihan dimulai dari sosialisasi program, pelatihan teoritis pembuatan bata cetak, penyiapan alat dan bahan, dan praktek lapangan pembuatan bata cetak. Para penambang kelompok UMK yang hadir dalam kegiatan tersebut sebanyak 20 orang. Metode praktek dilakukan dengan mempraktekan langsung penggunaan mesin pengaduk bahan baku bata cetak tailing bijih mangan dan pembuatan bata cetak tanpa pembakaran. Peserta pelatihan dibekali tatacara dan praktek proses pengeringan, penumbukan dan pengayakan limbah tailing, kemudian pencampuran limbah tailing halus dengan perekat sodium silikat. Setelah melalui proses pelatihan, terdapat peningkatan wawasan dan pengetahuan pembuatan bata cetak tanpa pembakaran, tersedianya tempat pembuatan bata cekat, dan kepuasan tersendiri bagi penambang yang berujung pada terciptanya peluang usaha baru.
\end{abstract}

Kata kunci: Tailing tambang mangan, perekat sodium silikat, sodium hidroksida, bata cetak tanpa pembakaran

\section{ABSTRACT}

During 2014-2016, the total production of manganese ore in Setiawaras Village, Kec. Cibalong, Kab. Tasikmalaya was around 2,520 tons/year. For every ton of manganese ore produced, two tons of manganese ore tailings are issued. Based on the current production level, it can be estimated that around 5,040 tons of manganese ore mine tailings are produced annually in Setiawaras Village. These manganese ore tailings are left alone on roadside, shelter ponds, empty places and mining areas. Therefore, a breakthrough needs to be made that can help utilize abundant manganese tailings as well as assistance in the preparation of processing technology. The training implementation method starts from the socialization of the program, the theoretical training in making brickwork, preparation of tools and materials, and the practice of making brickwork. Participants who attended the event were 20 people. The practice method is carried out by practicing directly the use of manganese brick molding mixer and making bricks without burning. The training participants were provided with procedures and practices for the process of drying, pulverizing and sifting tailings, then mixing fine tailings waste with sodium silicate adhesive. After going through the training process, there is an increase in the insight and knowledge of making bricks without combustion, the availability of fixed brick making, and its own satisfaction for miners which results in the creation of new business opportunities.

Keywords: Manganese mine tailings, sodium silicate adhesives, sodium hydroxide, bricks without combustion 


\section{PENDAHULUAN}

Kec. Cibalong, Kab. Tasikmalaya berada $32 \mathrm{~km}$ dari Universitas Siliwangi dan mempunyai luas wilayah 58,62 $\mathrm{km}^{2}$ dengan jumlah penduduk 3.349 orang. Potensi utama Kec. Cibalong adalah tambang bijih mangan yang berada di Desa Setiawaras. Itu menyumbang sekitar 47\% nilai total semua sumber daya di Kec. Cibalong. Selama 2014-2016, produksi total bijih mangan rakyat adalah sekitar 2.520 ton/tahun (BPS Kab. Tasikmalaya, 2015). Salah satu usaha yang telah menjadi kegiatan masyarakat di Desa Setiawaras sejak beberapa waktu yang lalu adalah usaha eksplorasi bijih mangan secara perorangan. Dua mitra yang melakukan kegiatan usaha tersebut adalah Perusahaan Bara Abadi dipimpin oleh Asep Sutarjo dan Cicarangka Jaya oleh Ajo Sarjo berlokasi di Desa Setiawaras, Kec. Cibalong, Kab. Tasikmalaya. Usaha kedua mitra digolongkan sebagai usaha skala mikro dan kecil (UMK) tambang yang memiliki jumlah tenaga kerja sebagai penambang rata-rata sepuluh orang. Eksplorasi dilakukan secara manual menggunakan peralatan sederhana. Eksplorasi bijih mangan menghasilkan limbah sisa dalam bentuk tailing mangan dari hasil pencucian. Meskipun tidak ada mekanisme pelaporan yang tepat yang dapat membantu mendokumentasikan jumlah tailing tambang bijih mangan yang diproduksi di Desa Setiawaras, perkiraan berdasarkan informasi yang dibuat oleh kedua mitra perusahaan menunjukkan bahwa untuk setiap ton bijih mangan yang dihasilkan, dua ton tailing bijih mangan dikeluarkan (Wawancara personal, 7 Maret 2018). Berdasarkan tingkat produksi saat ini, dapat diperkirakan bahwa sekitar 5.040 ton tailing tambang bijih mangan diproduksi setiap tahun di Desa Setiawaras. Tailing bijih mangan ini ditinggalkan begitu saja di pinggir-pinggir jalan, kolam penampungan, tempat-tempat kosong dan area pertambangan.

Menurut Royani (2017), tailing bijih mangan Karangnunggal merupakan campuran material yang terdiri dari 30,12\% $\mathrm{MnO}_{2}, 12,19 \% \mathrm{SiO}_{2}$, dan 3\% CaO, tanah liat, kapur dan lain-lain. Kandungan mangan $\mathrm{MnO}_{2}$ yang terkandung pada tanah di daerah tambang memberi kontribusi meningkatnya kadar mangan pada sumur gali di area pemukiman penduduk sekitar pertambangan mangan. Rata-rata penambangan mangan berada sekitar 10 meter dari area pemukiman penduduk. Hasil penelitian yang dilakukan oleh Setiono (2014) menunjukkan bahwa terdapat 29 sumur gali dari 42 sumur gali yang tercemari mangan dengan konsentrasi melebihi kadar mangan yang dipersyaratkan oleh Permenkes Nomor 416/1190. Selanjutnya, berdasarkan komposisinya, tailing bijih mangan mengandung pasir silika $\left(\mathrm{SiO}_{2}\right)$ yang berfungsi untuk mengurangi penyusutan dan mempermudah pengeringan bata cetak. Menurut penelitian yang dilakukan oleh Elhusna (2014) dan Herlina (2015), penyusutan volume yang terjadi pada bata cetak sekitar 30\% ketika bata cetak hanya menggunakan tanah lempung tanpa menggunakan campuran pasir. Kapur berfungsi sebagai perekat dalam adukan bata cetak. Pengikatan dan pengerasan kapur terjadi karena reaksi kimia. Pada reaksi ini air sebagai pelarut memegang peranan penting. Pengerasan udara terjadi karena kapur mengikat $\mathrm{CO}_{2}$ dari udara. Pengerasan kapur di dalam air disebabkan oleh reaksi-reaksi kimia yang lebih komplek antara ikatan $\mathrm{C}(\mathrm{HO}) 2$ dengan silika, alumina dan oksida besi yang terkandung pada tailing bijih mangan (Nurlina dkk, 2014).

Atas dasar diuraikan di atas, maka masalah prioritas yang perlu ditangani melalui kegiatan pengabdian ini, yaitu:

a. Tailing tambang bijih mangan menyebabkan pencemaran tanah dan air tanah. 
b. Penumpukan tailing tambang bijih mangan mengganggu dan mempersempit lahan untuk aktivitas penambangan bijih mangan. Berdasarkan komposisi tailing bijih mangan, itu menganjurkan bahwa tailing memungkinkan untuk diolah menjadi bata cetak berkualitas.

Tujuan kegiatan PKM ini adalah mencari pemecahan terhadap masalah di atas sebagai berikut.

a. Meningkatkan nilai tambah tailing tambang bijih mangan melalui industri hilir pengolahan tailing menjadi bata cetak untuk bahan bangunan,

b. Meningkatkan pengetahuan, wawasan dan ketrampilan kelompok UMK dalam pembuatan bata cetak tanpa pembakaran dari tailing tambang bijih mangan,

\section{BAHAN DAN METODE}

1. Kegiatan Persiapan

Kegiatan dirancang dengan pendekatan dan sharing dengan kelompok UMK Tambang Bara Abadi dipimpin oleh Asep Sutarjo dan Cicarangka Jaya oleh Ajo Sarjo berlokasi di Desa Setiawaras, Kec. Cibalong, Kab. Tasikmalaya, karena untuk terlaksananya kegiatan PKM ini dengan baik akan sangat membutuhkan dukungan sepenuhnya dari mereka untuk memberikan pengertian akan pentingnya manfaat kegiatan pengabdian ini bagi usaha mereka terutama dukungan waktu, tenaga dan pikiran dimana anggota mitra harus fokus dalam melaksanakan kegiatan ini dan meluangkan waktunya untuk melakukan kegiatan.

2. Pelaksanaan Kegiatan

Pelaksanaaan kegiatan pembuatan bata cetak tanpa pembakaran dari tailing tambang mangan diberikan kepada 20 orang penambang karang taruna dari UMK Tambang Bara Abadi dan Cicarangka Jaya di Desa Setiawaras, Kec. Cibalong, Kab. Tasikmalaya. Pelaksanaan kegiatan ini menggunakan metode pelatihan dan metode praktek (learning by doing) dengan memberikan praktek pembuatan pembuatan bata cetak. Tabel 1 dan 2 berturut-turut menunjukkan tahap-tahap kegiatan pelatihan dan jadwal pelatihan pembuatan bata cetak tanpa pembakaran.

Tabel 1. Tahap-tahap kegiatan pelatihan pembuatan bata cetak tanpa pembakaran

\begin{tabular}{|c|c|c|c|}
\hline No & Kegiatan & Penjelasan & Sasaran \\
\hline 1 & Sosialisasi & 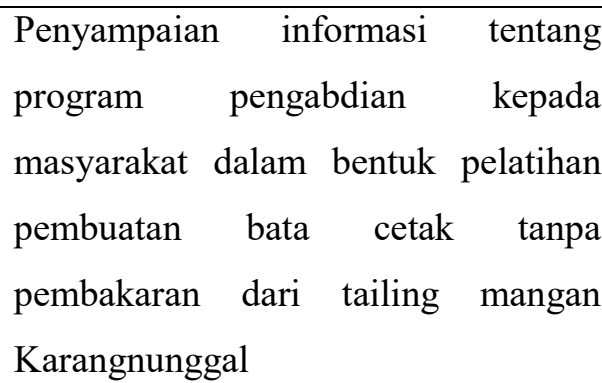 & Tim pengabdian \\
\hline 2 & Perencanaan & $\begin{array}{l}\text { Tim mengumpulkan data tentang } \\
\text { penambang, tempat, alat, bahan baku } \\
\text { dan prasarana, bahan materi dan } \\
\text { praktek }\end{array}$ & $\begin{array}{l}\text { Tim pengabdian dan } \\
\text { Mitra }\end{array}$ \\
\hline
\end{tabular}




\begin{tabular}{|l|l|l|l|}
\hline \multicolumn{1}{|c|}{ No } & \multicolumn{1}{|c|}{ Kegiatan } & \multicolumn{1}{|c|}{ Penjelasan } & \multicolumn{1}{|c|}{ Sasaran } \\
\hline 3 & Pelaksanaan & $\begin{array}{l}\text { Melakukan pelatihan pembuatan bata } \\
\text { cetak tanpa pembakaran dengan cara } \\
\text { didampingi nara sumber dan tim } \\
\text { pengabdi }\end{array}$ & Penambang \\
\hline 4 & Evaluasi & $\begin{array}{l}\text { Narasumber dan tim pengabdian } \\
\text { menilai hasil kerja peserta }\end{array}$ & Penambang \\
\hline 5 & Pelaporan & $\begin{array}{l}\text { Tim pengabdi membuat laporan } \\
\text { kegiatan dari awal sampai akhir } \\
\text { kegiatan }\end{array}$ & \\
\hline
\end{tabular}

Tabel 2. Jadwal pelatihan pembuatan bata cetak tanpa pembakaran

\begin{tabular}{|c|c|c|c|}
\hline Tanggal & Waktu & Materi & Metode \\
\hline \multirow{6}{*}{$\begin{array}{c}\text { Jumat, } \\
31 \text { Agustus } 2018\end{array}$} & $08.30-09.00$ & Pembukaan & \\
\hline & $09.00-11.00$ & $\begin{array}{l}\text { Mangan sebagai bahan } \\
\text { baku industri }\end{array}$ & Ceramah \\
\hline & $11.00-12.00$ & Produk tailing mangan & Ceramah \\
\hline & $12.00-13.00$ & \multicolumn{2}{|c|}{ Soliskan } \\
\hline & $13.00-14.00$ & $\begin{array}{l}\text { Tailing mangan untuk } \\
\text { bata cetak }\end{array}$ & Ceramah \\
\hline & $14.00-16.00$ & $\begin{array}{l}\text { Mengapa bata cetak } \\
\text { tidak perlu dibakar }\end{array}$ & $\begin{array}{c}\text { Ceramah, tanya } \\
\text { jawab }\end{array}$ \\
\hline \multirow{5}{*}{$\begin{array}{c}\text { Sabtu, } \\
\text { 1 September } 2018\end{array}$} & $09.00-11.00$ & $\begin{array}{l}\text { Model perekat untuk } \\
\text { bata cetak }\end{array}$ & $\begin{array}{c}\text { Ceramah, tanya } \\
\text { jawab }\end{array}$ \\
\hline & $11.00-12.00$ & $\begin{array}{l}\text { Pengenalan mesin } \\
\text { pencampur dan pencetak }\end{array}$ & $\begin{array}{c}\text { Ceramah, tanya } \\
\text { jawab }\end{array}$ \\
\hline & $12.00-13.00$ & \multicolumn{2}{|c|}{ Soliskan } \\
\hline & $13.00-14.00$ & $\begin{array}{l}\text { Ukuran partikel tailing } \\
\text { mangan untuk bata } \\
\text { cetak }\end{array}$ & $\begin{array}{l}\text { Ceramah, tanya } \\
\text { jawab, praktek }\end{array}$ \\
\hline & $14.00-16.00$ & Komposisi bata cetak & $\begin{array}{l}\text { Ceramah, tanya } \\
\text { jawab, praktek }\end{array}$ \\
\hline \multirow{6}{*}{$\begin{array}{c}\text { Minggu, } \\
\text { 2 September } 2018\end{array}$} & $09.00-11.00$ & $\begin{array}{l}\text { Praktek pembuatan } \\
\text { serbuk mangan }\end{array}$ & $\begin{array}{l}\text { Ceramah, tanya } \\
\text { jawab, praktek }\end{array}$ \\
\hline & $11.00-12.00$ & $\begin{array}{l}\text { Praktek pencampuran } \\
\text { bata cetak }\end{array}$ & $\begin{array}{l}\text { Ceramah, tanya } \\
\text { jawab, praktek }\end{array}$ \\
\hline & $12.00-13.00$ & \multicolumn{2}{|c|}{ Soliskan } \\
\hline & $13.00-14.00$ & $\begin{array}{l}\text { Praktek pencetakan bata } \\
\text { cetak bag. } 1\end{array}$ & $\begin{array}{l}\text { Ceramah, tanya } \\
\text { jawab, praktek }\end{array}$ \\
\hline & $14.00-16.00$ & $\begin{array}{l}\text { Praktek pencetakan bata } \\
\text { cetak bag. } 2\end{array}$ & $\begin{array}{l}\text { Ceramah, tanya } \\
\text { jawab, praktek }\end{array}$ \\
\hline & $16.00-16.15$ & Penutupan & \\
\hline
\end{tabular}

Tahapan-tahapan kegiatan praktek pembuatan bata cetak tanpa pembakaran adalah sebagai berikut:

1. Mempersiapkan tailing mangan yang diambil dari kegiatan penambangan masyarakat di Kampung Cicarangka, Desa Setiawaras, Kec. Cibalong. 
2. Membersihkan tailing mangan secara manual.

3. Mengeringkan tailing mangan bersih di bawah cahaya matahari.

4. Menumbuk tailing mangan kering menggunakan alat penumbuk besi.

5. Mengayak taling mangan menggunakan ayakan berukuran kurang dari 5 mesh $(4 \mathrm{~mm})$ dan kemudian diayak ulang dengan ayakan berukuran 170 mesh $(88 \mu \mathrm{m})$.

6. Mencampurkan tailing mangan dan campuran sodium hidroksida dan sodium silikat. Perbandingan campuran adalah $4 \mathrm{~kg}$ tailing mangan berukuran 150 - 5 mesh, $4 \mathrm{~kg}$ taling mangan kurang dari 5 mesh, dan $3 \mathrm{~kg}$ campuran sodium hidroksida dan sodium silikat.

7. Mencetak campuran ke dalam cetakan berbentuk balok dengan ukuran panjang $30 \mathrm{~cm}$, lebar $15 \mathrm{~cm}$ dan tebal $10 \mathrm{~cm}$.

8. Mengeringkan bata cetak selama $3-4$ minggu.

\section{Pendampingan}

Kegiatan pendampingan kelompok mitra akan dilakukan dalam 2 (dua) bentuk sebagai berikut:

1) Pendampingan secara teknis dilakukan dengan menempatkan pendamping mahasiswa yang dapat memantau kegiatan mitra memberikan solusi atas permasalahan manajemen yang terjadi.

2) Pendampingan secara teknis dilakukan dengan menempatkan pendamping secara periodik untuk memantau kegiatan mitra dan memberikan solusi atas permasalahan teknik produksi yang terjadi.

4. Monitoring dan Evaluasi

Proses monitoring dan evaluasi secara periodik akan dilakukan sampai kelompok mitra bisa mandiri dalam menghasilkan produk bata cetak dan menjalankan usahanya secara berkelanjutan sehingga secara keseluruhan tujuan, target dan luaran kegiatan pengabdian ini dapat tercapai dengan baik. Tabel 3 dan 4 berturut-turut menunjukkan angket pelaksanaan kegiatan PPM dan intrumen monitoring dan evaluasi PPM. Angket pelaksanaan kegiatan PPM diberikan ke peserta pelatihan setelah pelatihan dilaksanakan dan monitoring dilakukan setelah pendampingan dilakukan.

Tabel 3. Data angket pelaksanaan kegiatan PPM

\begin{tabular}{|c|l|}
\hline No & \multicolumn{1}{|c|}{ Item pertanyaan } \\
\hline 1 & Kesesuaian kegiatan pengabdian dengan kebutuhan masyarakat \\
\hline 2 & Kerjasama pengabdi dengan masyarakat peserta pelatihan \\
\hline 3 & Memunculkan aspek pemberdayaan masyarakat \\
\hline 4 & Meningkatkan motivasi masyarakat untuk berkembang \\
\hline 5 & Sikap/perilaku pengabdi di lokasi pengabdian \\
\hline 6 & Komunikasi/ koordinasi Tim Pengabdi dengan masyarakat \\
\hline 7 & Kesesuaian waktu pelaksanaan dengan kegiatan masyarakat \\
\hline 8 & Kesesuaian keahlian pengabdi dengan kegiatan pengabdian \\
\hline 9 & Kemampuan mendorong kemandirian/ swadaya masyarakat \\
\hline 10 & Hasil pengabdian dapat dimanfaatkan masyarakat \\
\hline
\end{tabular}


Tabel 4. Intrumen monev setelah kegiatan PPM

\begin{tabular}{|l|l|}
\hline No & \multicolumn{1}{|c|}{ Item pertanyaan } \\
\hline 1 & Peserta trampil menggunakan mesin pencetak \\
\hline 2 & Peserta trampil membuat adonan bata cetak \\
\hline 3 & Peserta trampil mengeringkan bata cetak \\
\hline 4 & Peserta trampil membuat bata cetak dengan ukuran tepat \\
\hline 5 & Peserta membuat bata cetak tanpa cacat \\
\hline 6 & Peserta membuat 200 bata cetak dalam satu hari \\
\hline 7 & Peserta membuat bata cetak berkadar air kurang $20 \%(\mathrm{Standar} \mathrm{SNI})$ \\
\hline 8 & $\begin{array}{l}\text { Peserta membuat bata cetak dengan kuat tekan } 100 \mathrm{~kg} / \mathrm{cm}^{2}(\mathrm{Standar} \\
\text { SNI) }\end{array}$ \\
\hline 9 & $\begin{array}{l}\text { Peserta membuat bata cetak dengan densitas antara } 1,6-2,5 \mathrm{~g} / \mathrm{cm}^{2} \\
(\text { Standar SNI) }\end{array}$ \\
\hline
\end{tabular}

\section{HASIL}

Kegiatan pengabdian ini dilakukan melalui pelatihan dan praktek pembuatan bata cetak tanpa pembakaran di Desa Setiawaras, Kec. Cibalong, Kabupaten Tasikmalaya. Pelatihan dan praktek dilaksanakan pada hari Jumat, 31 Agustus 2018 sampai Minggu, 2 September 2018 di Desa Setiawaras, Kec. Cibalong, Kabupaten Tasikmalaya. Para Penambang Karangtaruna yang hadir dalam kegiatan tersebut sebanyak 20 orang dari dua kelompok mitra Bara Abadi dan Cicarangka Jaya. Gambar 1 menunjukkan kegiatan pengabdian pada pelatihan pembuatan bata cetak tanpa pembakaran di Desa Setiawaras, Kec. Cibalong, Kab. Tasikmalaya.
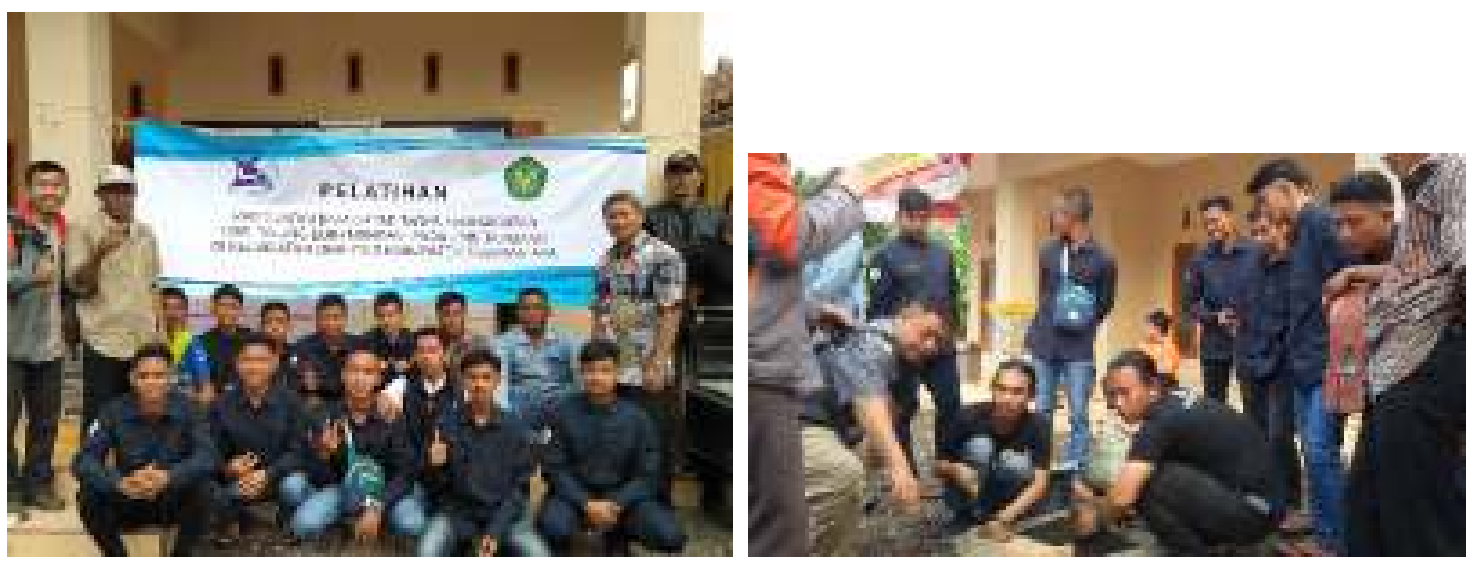

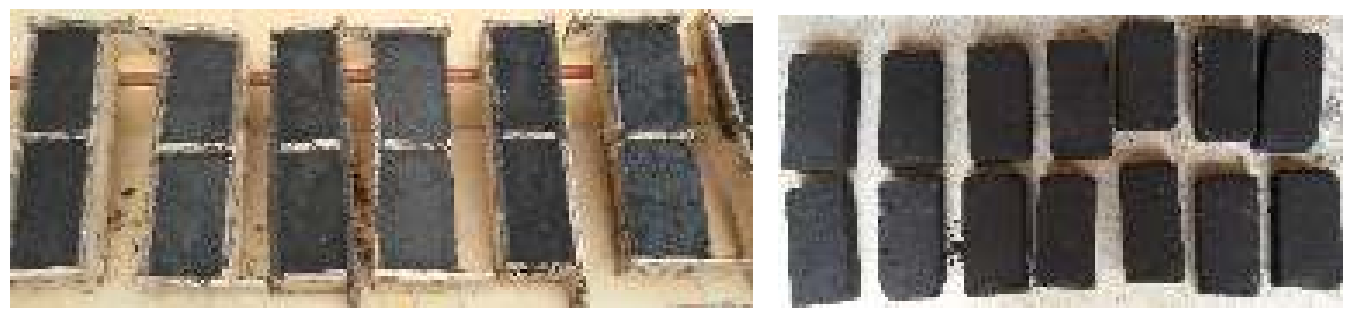

Gambar 1. Kegiatan pengabdian pada pelatihan pembuatan bata cetak tanpa pembakaran di Desa Setiawaras, Kec. Cibalong, Kab. Tasikmalaya.

Tabel 5 menunjukkan data ketercapaian pelaksanaan pelatihan pembuatan bata cetak dari tailing mangan tanpa pembakaran. Itu menunjukkan bahwa hampir semua item pertanyaan dijawab oleh masyarakat/peserta pelatihan dengan jawaban katagori sangat baik. Ini berarti bahwa para pengrajin memiliki semangat yang tinggi dalam mengikuti kegiatan penyuluhan dan pelatihan dan menunjukan kerja sama yang baik dalam pelatihan membuat bata cetak. Banyak dari para pengrajin mengajukan pertanyaan berkaitan dengan cara pembuatan bata cetak. Pada saat praktek pembuatan bata cetak itu dilakukan beberapa kali percobaan pembuatan bata cetak. Selama berlangsungnya acara penyuluhan dan pelatihan, para peserta cukup antusias mengikuti materi yang disampaikan oleh pemateri. Demikian halnya pada kegiatan praktek, partisipasi para peserta sangat dominan, sehingga tingkat serapan terhadap materi sangat baik.

Tabel 5. Data ketercapaian pelaksanaan kegiatan pelatihan pembuatan bata cetak tanpa pembakaran.

\begin{tabular}{|l|c|c|c|}
\hline Item pertanyaan & Skor & Prosentase & Katagori \\
\hline $\begin{array}{l}\text { Kesesuaian kegiatan pengabdian dengan } \\
\text { kebutuhan masyarakat }\end{array}$ & 3,12 & 81,22 & Sangat baik \\
\hline $\begin{array}{l}\text { Kerjasama pengabdi dengan masyarakat } \\
\text { peserta pelatihan }\end{array}$ & 3,42 & 86,1 & Sangat baik \\
\hline $\begin{array}{l}\text { Memunculkan aspek pemberdayaan } \\
\text { masyarakat }\end{array}$ & 3,31 & 84,4 & Sangat baik \\
\hline $\begin{array}{l}\text { Meningkatkan motivasi masyarakat untuk } \\
\text { berkembang }\end{array}$ & 3,23 & 82,13 & Sangat baik \\
\hline $\begin{array}{l}\text { Sikap/perilaku pengabdi di lokasi pengabdian } \\
\text { Komunikasi/ koordinasi Tim Pengabdi dengan } \\
\text { masyarakat }\end{array}$ & 3,21 & 81,67 & Sangat baik \\
\hline $\begin{array}{l}\text { Kesesuaian waktu pelaksanaan dengan } \\
\text { kegiatan masyarakat }\end{array}$ & 3,16 & 80,98 & Sangat baik \\
\hline $\begin{array}{l}\text { Kesesuaian keahlian pengabdi dengan kegiatan } \\
\text { pengabdian }\end{array}$ & 3,35 & 85,14 & Sangat baik \\
\hline
\end{tabular}




\begin{tabular}{|l|c|c|c|}
\hline Item pertanyaan & Skor & Prosentase & Katagori \\
\hline $\begin{array}{l}\text { Kemampuan mendorong kemandirian/ } \\
\text { swadaya masyarakat }\end{array}$ & 3,08 & 78,7 & Baik \\
\hline $\begin{array}{l}\text { Hasil pengabdian dapat dimanfaatkan } \\
\text { masyarakat }\end{array}$ & 3,11 & 80,12 & Sangat baik \\
\hline
\end{tabular}

Tabel 6 menunjukkan ketercapaian pelatihan pembuatan bata cetak tanpa pembakaran. Data ini diambil selama pendampingan, monitoring dan evaluasi. Selama pendampingan, peserta pelatihan melalukan kegiatan penumbukan dan pengayakan tailing mangan dengan menghasilkan dua ukuran partikel tailing mangan yaitu ukuran 150 - 5 mesh dan 5 mesh. Bata cetak yang dihasilkan dari tailing mangan berukuran kurang dari 5 mesh, itu menghasilkan bata cetak yang tidak mudah terbentuk dalam cetakan, karena campuran tailing mangan dan sodium hidroksida dan sodium silikat membentuk slurry sehingga bata cetak tampak selalu basah. Setelah disimpan selama 3 minggu, bata cetak tidak kering, sehingga ketika dilepaskan dari cetakannya bentuk bata tidak beraturan dan tidak membentuk ukuran sesuai dengan ukuran cetakan. Bata cetak yang menggunakan bahan baku tailing mangan berukuran kurang dari 5 mesh $(88 \mu \mathrm{m})$ tidak kering setelah dikeringkan selama 3 minggu, hal ini disebabkan oleh kurangnya poripori yang terbentuk antara partikel tailing mangan, sehingga cairan yang berada di dalam bata cetak tidak bisa diuapkan.

Bata cetak yang dibuat dari campuran tailing mangan yang ukurannya berbeda menghasilkan bata cetak kering. Komposisi untuk bata cetak ini adalah $4 \mathrm{~kg}$ tailing mangan berukuran $88 \mu \mathrm{m}-4 \mathrm{~mm}, 4 \mathrm{~kg}$ tailing mangan berukuran kurang $4 \mathrm{~mm}$ dan $3 \mathrm{~kg}$ campuran sodium hidroksida dan sodium silikat. Kapasitas campuran ini mempunyai 5 bata cetak berbentuk balok dengan ukuran panjang $30 \mathrm{~cm}$, lebar $15 \mathrm{~cm}$ dan tebal $10 \mathrm{~cm}$. Ukuran bata cetak sesuai dengan ukuran dari cetakannya dan tidak mengalami cacat. Bata cetak dengan komposisi ini menghasilkan kuat tekan sekitar 2,4 MPa ketika dikeringkan selama 3 minggu. Perbedaannya dengan bata cetak yang dibuat dari tailing mangan ukuran $88 \mu \mathrm{m}$ ialah bahwa pada bodi cetak menyediakan pori-pori untuk jalan masuknya penguapan air. Bata cetak ini adalah bata cetak terbaik untuk digunakan sebagai bahan bangunan.

Tabel 6. Ketercapaian pelatihan pembuatan bata cetak tanpa pembakaran

\begin{tabular}{|l|c|c|}
\hline \multicolumn{1}{|c|}{ Item pertanyaan } & Prosentase & Katagori \\
\hline Peserta trampil menggunakan mesin pencetak & 86,12 & Sangat baik \\
\hline Peserta trampil membuat adonan bata cetak & 88,67 & Sangat baik \\
\hline Peserta trampil mengeringkan bata cetak & 100 & Sangat baik \\
\hline Peserta trampil membuat bata cetak dengan ukuran tepat & 83,45 & Sangat baik \\
\hline Peserta membuat bata cetak tanpa cacat & 81,12 & Sangat baik \\
\hline Peserta membuat 100 bata cetak dalam satu hari & 74,65 & Baik \\
\hline
\end{tabular}




\begin{tabular}{|l|c|c|}
\hline \multicolumn{1}{|c|}{ Item pertanyaan } & Prosentase & Katagori \\
\hline Peserta membuat bata cetak berkadar air kurang $20 \%$ & 87,19 & Sangat baik \\
\hline Peserta membuat bata cetak dengan kuat tekan $100 \mathrm{~kg} / \mathrm{cm}^{2}$ & 87,19 & Sangat baik \\
\hline $\begin{array}{l}\text { Peserta membuat bata cetak dengan densitas antara } 1,6-2,5 \\
\mathrm{~g} / \mathrm{cm}^{2}\end{array}$ & 87,19 & Sangat baik \\
\hline
\end{tabular}

\section{PEMBAHASAN}

Pada pembahasan ini diuraikan secara terperinci beberapa wawasan dan keterampilan peserta pelatihan yang didaftar pada Tabel 6. Bata cetak untuk bahan bangunan konstruksi diproduksi dengan dua cara yaitu produksi bata cetak dengan pembakaran dan tanpa pembakaran. Produksi bata cetak dengan pembakaran biasanya menggunakan bahan baku tanah liat dan bahan campuran lain yang mengandung bahan selulosa sedemikian sehingga setelah pembakaran bata cetak berbobot ringan. Kemudian produksi bata cetak tanpa pembakaran umumnya campuran bahan baku menggunakan bahan semen sebagai bahan perekat. Bata cetak tanpa pembakaran proses akhirnya bukan pembakaran tetapi hanya pengeringan sehingga bata cetak dapat dikeringkan secara perlahan. Bata cetak tanpa pembakaran yang dibuat pada kegiatan pengabdian ini adalah menggunakan bahan baku tailing atau bahan sisa bijih mangan yang diambil dari Desa Setiawaras, Kec. Cibalong, kab. Tasikmalaya. Komposisi utama tailing mangan adalah 70 wt.\% mangan dan $25 \mathrm{wt} . \%$ silika. Pada proses pengadonan tailing mangan, campuran sodium hidroksida $(\mathrm{NaOH})$ dan sodium silikat $\left(\mathrm{Na}_{2} \mathrm{SiO}_{3}\right)$ digunakan sebagai perekat bata cetak. Untuk proses pencetakan bata cetak dilakukan secara manual dan menggunakan mesin pencetak. Ukuran dimensi tempat cetakan secara manual dan menggunakan mesin adalah panjang $30 \mathrm{~cm}$, lebar $15 \mathrm{~cm}$ dan tebal $10 \mathrm{~cm}$. Ukuran ini lebih besar dari ukuran standar untuk bangunan menurut SNI 15-2094-2000 (Budi Wicaksana dkk, 2016) yaitu ukuran panjang $23 \mathrm{~cm}$, lebar $11 \mathrm{~cm}$ dan tebal $5 \mathrm{~cm}$. Dengan menggunakan bahan baku tailing mangan yang mempunyai ikatan kuat antara partikel, maka memungkinkan membentuk kesatuan tunggal yang kuat menjadi bata cetak setelah dicampur dengan perekat menggunakan ukuran pencetakan yang lebih besar. Proses pengeringan bata cetak dilakukan pada temperatur ruangan selama 2-3 hari, dan kemudian dilanjutkan untuk aging selama 3-4 minggu pada temperatur lembab, terhindar dari hujan dan panas matahari. Karakteristik yang sama diperoleh untuk bata cetak tanpa pembakaran yang dibuat dari campuran $60 \%$ tanah liat, 30\% kapur dan abu sekam padi dan 10\% semen (Darwis dkk, 2016). Ketika dilakukan aging selama 28 hari, kuat tekan bata cetak dan kadar resapan air berturut-turut adalah $21.20 \mathrm{~kg} / \mathrm{cm}^{2}$ dan 36,19\% yang diperoleh untuk 22,5\% kapur dan 7,5 abu sekam padi. Proses pengeringan dan aging pada bata cetak tanpa pembakaran dari tailing mangan lebih cepat dari yang dilakukan oleh $\mathrm{Du}$ (2012) yang menggunakan perekat semen pada pembuatan bata cetak dari tailing bijih besi

Sebagai perbandingan untuk ukuran partikel bahan baku bata cetak, itu telah dilaporkan bahwa bata cetak mempunyai kuat tekan 20,13 MPa untuk bata cetak tanpa pembakaran yang dibuat dari campuran tanah tercemar logam berat berukuran 100 mesh dan semen yang dikeringkan selama 28 hari (Dai dkk, 2014) dan selanjutnya Kuranchi dkk (2014) telah membuat bata cetak tanpa pembakaran dari tailing besi 
berukuran lebih kecil dari $175 \mu \mathrm{m}$ dan campuran sodium hidroksida dan sodium silikat. Itu menghasilkan kuat tekan bata cetak adalah 50, $35 \mathrm{MPa}$ setelah dikeringkan selama satu minggu. Beberapa hasil menunjukkan bahwa ukuran partikel bahan baku bata cetak berpengaruh terhadap karakteristik bata cetak terutama kuat tekan bata cetak, dan ukuran partikel lebih besar dari $50 \mu \mathrm{m}$ menghasilkan kuat tekan yang ordenya MPa.

Berdasarkan data ketercapaian pelatihan pembuatan bata cetak tanpa pembakaran pada Tabel 6, itu menunjukkan bahwa jumlah peserta terampil berada di atas $80 \%$ dari peserta keseluruhan pada berbagai katagori keterampilan dalam pembuatan bata cetak tanpa pembekaran. Namun peserta tidak bisa mencetak yang melebihi 100 bata cetak dapat diproduksi setiap hari. Secara umum, hal ini berarti bahwa ketercapaian kegiatan ini berkatagori sangat baik. Hasil yang dicapai menunjukkan bahwa peserta pelatihan sudah mampu mempraktekan sendiri wawasan dan keterampilan yang diperoleh selama pelatihan.

Selanjutnya, pemberdayaan masyarakat penambang melalui pelatihan pembuatan bata cetak ini mempunyai potensi pengembangan bisnis yang tinggi. Setelah bata cetak dari tailing mangan diproduksi, itu bisa dipasarkan sebagai bahan bangunan. Produksi bata cetak ini akan terus menerus karena bahan baku tailing mangan akan berlimpah jika penambangan mangan terus dilakukan oleh masyarakat lokal.

\section{KESIMPULAN DAN SARAN}

1. Kesimpulan

a. Hasil angket kegiatan menunjukkan bahwa kepuasan peserta mengikuti kegiatan pelatihan pembuatan bata cetak tanpa pembakaran dari tailing mangan mencapai di atas $80 \%$ yang berarti para peserta cukup antusias mengikuti materi teori maupun praktek yang disampaikan oleh pemateri. Namun kekurangan terjadi pada komunikasi yang terbangun antara pemateri dan peserta selama kegiatan berlangsung sehingga perlu perbaikan dan diharapkan ada pengabdian masyarakat lanjutan untuk menindaklanjuti kekurangan dalam pengabdian masyarakat selanjutnya.

b. Hasil evaluasi kegiatan pada penyerapan materi pelatihan menunjukkan bahwa di atas $80 \%$ dari jumlah peserta pelatihan sudah dikatagorikan terampil sangat baik dalam pembuatan bata cetak tanpa pembakaran dari tailing mangan mulai dari pembuatan partikel-partikel halus, pencampuran atau pengadonan, pencetakan, dan pengeringan.

c. Hasil pengujian parameter kadar air, kuat tekan dan densitas bata cetak tanpa pembakaran yang dibuat oleh peserta sudah sesuai dengan standar SNI.

d. Hasil yang dicapai menunjukkan bahwa peserta pelatihan sudah mampu mempraktekan sendiri wawasan dan keterampilan yang diperoleh selama pelatihan, sehingga peserta dapat membuat bata cetak tanpa pembakaran secara mandiri tanpa bantuan pendampingan.

\section{Saran}

a. Kelompok pengrajin bata cetak tanpa bakar sudah dibentuk, oleh karena itu perlu adanya pemantauan dari pemerintah daerah, dalam hal ini dapat dari pemerintah desa atau dinas 
perindustrian untuk peningkatan pengelolaan kelompok pengrajin.

b. Bagi masyarakat pengrajin bahwa teknologi pembuatan bata cetak tanpa bakar sudah dipahami dengan baik, selanjutnya peserta harus dapat mengembangkan teknologi tersebut untuk meningkatkan pendapatan sebagai pengembangan bisnis keluarga atau kelompok.

\section{UCAPAN TERIMA KASIH}

Penulis mengucapkan terima kasih kepada Direktorat Riset dan Pengabdian Masyarakat, Kementerian Riset, Teknologi, dan Pendidikan Tinggi yang telah mendanai kegiatan pengabdian kepada masyarakat melalui Program Kemitraan Masyarakat (PKM) Tahun 2018 dengan Nomor Kontrak . Di samping itu, penulis juga ingin mengucapkan banyak terima kasih kepada Bapak Asep Sutarjo dari UMK Tambang Bara Abadi dan Bapak Ajo Sarjo UMK Tambang Cicarangka Jaya berlokasi di Desa Setiawaras, Kec. Cibalong, Kab. Tasikmalaya.

\section{DAFTAR PUSTAKA}

Andik, S., (2014). “Studi Kadar Mangan (Mn) Pada Air Sumur Gali Di Desa Karangnunggal Kecamatan Karangnunggal Kabupaten Tasikmalaya, Jurnal Kesehatan Komunitas Indonesia”, Vol. 10, hal. 973 981.

BPS, Badan Pusat statistik Kab. Tasikmalaya, 2015.

Dai, D., Li, D., Ren, L., 2014. "Technology of non-burned brick using heavy metal polluted soil and solidification of heavy metal", Advanced Materials Research, Vol. 955-959, hal. 2709-2713.

Du, G., Zuo, R., Guo, W., Liao, J., 2012. "Preparation of Construction Bricks from Iron Ore Tailings", Advanced Materials Research,Vol. 557-559, hal. 839-844.

Darwis, D., Ulum, S., Kurniawan, G., 2016. "Karakteristik Batu Bata Tanpa Pembakaran Berbahan Abu Sekam Padi dan Kapur Banawa”, Gravitasi, Vol. 15, hal. 1-9.

Elhusna, A. Wahyuni, dan A. Gunawan, (2014). "Performance of Clay Brick of Bengkulu, Procedia Engineering", Vol. 95, h.504-509.

Herlina, F., Elhusna, M. Islam, (2015). "Pengaruh Penambahan Pasir Sungai Pada Bata Merah Terhadap Kuat Tekan Dan Penyusutan Di Talang Kering Kota Bengkulu”, Jurnal Inersia, Vol. 7, h. 15 - 22.

Kuranchie, F., Shukla, S., Habibi, D., 2014. "Utilisation of iron ore mine tailings fof the production of geopolymer bricks", International Journal of Mining, Reclamation and Environment, Vol. 30, hal. $92-114$.

Nurlina, S., Taufik Hidayat, Hendro Suseno, E. M. Kharisma, (2014). "Pengaruh Penggunaan Limbah Batu Bata Sebagai Semen Merah Terhadap Kuat Tekan dan Kuat Tarik Mortar”, Jurnal Rekayasa Sipil, Vol. 8, hal. $136-141$.

Royani, A., R. Subagja dan A. Manaf, (2017). "Studi Pelindian Mangan Secara Reduksi Dengan Menggunakan Larutan Asam Sulfat, Jurnal Riset Teknologi Industri”, Vol.11, hal. 18 - 27. 
Witjaksana, B., Sarya, G., Widhiarto, H., 2016. "Pembuatan Batu Bata Tanpa Bakar Dengan Campuran Sodium Hiroksida (NaOH) dan Sodium Silikat (Na2SiO3)", JHP17 Jurnal Hasil Penelitian LPPM Untag Surabaya, Vol. 01, hal. 25 - 32. 